\title{
THE CASAMANCE AS AN AREA OF INTENSE LANGUAGE CONTACT: THE CASE OF BAÏNOUNK GUBAHER
}

\author{
Alexander Cobbinah \\ School of Oriental and African Studies, University of London
}

\section{Introduction}

Baïnounk is the cover term for a cluster of minority languages of Casamance, a region of Senegal with high linguistic diversity and a high concentration of small languages. Baïnounk languages belong to the Atlantic branch of Niger-Congo, specifically to the East SenegalGuinea languages and within this subgroup to the Nuun languages, together with the minority languages Kobiana (also: Buy) and Kasanga (also: Haaca), each spoken by a few hundred speakers in southern Senegal and Guinea-Bissau. The number of speakers for all Baïnounk languages together is estimated at around 15-20,000. Approximately 1,000 of these are speakers of the Gubaher variety, spoken in Djibonker just southwest of the provincial capital Ziguinchor, which will be the focus of this paper. Unless indicated otherwise, the data presented has been gathered during a four month field session as part of a $\mathrm{PhD}$ project conducted mainly in Djibonker in October 2009 - February 2010; recorded elicitation sessions have also been made in Niamone (Baïnounk Gunyaamolo), Djibelor (Baïnounk Gubelor) and Jegui/Guinea Bissau (Baïnounk Gujaxer). The project is part of an interdisciplinary DoBeS project connecting linguistics, archaeology and ethnobotany under the leadership of Dr. Friederike Lüpke (SOAS). For more detailed data on speaker numbers and other sociolinguistically relevant information on Baïnounk see Lüpke (this volume). The term Baïnounk is and has been understood to refer to one language; however, under closer inspection it becomes questionable that the different varieties grouped under this label constitute one language (the different and conflicting criteria for identifying a language notwithstanding). Not only are the differences in vocabulary and grammar substantial, distances between the different communities are large and contact between the different language areas is rather scarce. The Baïnounk language areas are like small islands scattered across a sea of Joola and Mandinka speaking populations. There is neither a unified "Baïnounk-identity" (see Lüpke, this volume and Lespinay 1996), nor an unequivocal cover term encompassing all of the groups in all of the varieties. We are dealing with rather isolated pockets of related but most often not mutually intelligible languages, spoken by people in different cultural surroundings who adhere to three different religions (Christian, Muslim, traditional) and communicate with outsiders in different sets of linguae francae.

The turbulent history of this small region has profoundly affected the linguistic situation in Casamance, producing a patchworked linguistic landscape characterized by high levels of 
language diversity and dialectal variation, five linguae francae and a very high degree of multilingualism. The importance of areal factors for the evolution of language in Africa has become more and more the focus of linguists' attention in recent years (Heine and Nurse 2008), and overall theoretical interest in this issue seems to be on the rise, yet there are still very few detailed studies of language contact at the micro-level. The conditions in Casamance are ideal for the purpose of investigating this issue, especially once more data from the so far undocumented Baïnounk languages become available, for various reasons:

1. The Baïnounk languages undoubtedly share a common genetic origin.

2. There is little or no contact between the different communities.

3. Each of the communities uses different contact languages from different genetic families (Mandinka (Mande), Joola languages (Atlantic), Portuguese Creole/Kriolu (Indo-European) and is characterised by different cultural influences.

In a scenario like this, which is far from unique in Africa, it quickly becomes obvious that language contact is indeed one of the driving forces of language evolution and change. The purpose of this article is to give a detailed account of the contact situation of which Baïnounk Gubaher is a part, give examples of contact driven phenomena especially surrounding the gender system, and outline further avenues of research to pursue in this area. I would go so far as to say that language contact is so pervasive in this area that a description of Bainounk would not be complete without taking into account its sociolinguistic setting and areal considerations, including the historical and cultural background. In addition, the Baïnounk cluster constitutes one of the largest missing pieces needed in order to solve the puzzle of the historical relationships between the languages of Casamance. As autochthonous languages of Casamance, it can safely be assumed that Baïnounk languages had a substratum influence in the past on the newcomer languages, but also that they have received material from surrounding languages later in its history (see de Lespinay 1997a), after it had ceased to be a dominant language in Casamance. Influences from and possibly on - other languages spoken in the region extend to all areas of grammar. Speculations on the role of contact influence in shaping the very complex noun class system of Baïnounk have sparked a theoretical debate on the peculiarities of this system (Sauvageot 1967; Dobrin 1995 and 1998; Dimitriadis 1997). I will take up this issue and present some more examples of contact-related topics surrounding the noun class system.

The Baïnounk language under scrutiny in this paper, Baïnounk Gubaher, is spoken by approximately 1,000 people in the village of Djibonker, just south of Ziguinchor, and by several hundred people of the diaspora communities in Dakar ${ }^{1}$ and Ziguinchor.

I will begin with a brief introduction to the history of the region and the linguistic landscape of Casamance in general and Djibonker specifically in order to make clear how pervasive language contact is in a highly multilingual and multicultural setting. I will then concentrate on the complex noun class system of Baïnounk, which has not only noun class prefixes but also plural suffixes. The core hypothesis of this section is that the complexity and hybridity of the system is not a direct result of language contact, but that language contact has nevertheless influenced the development of the system, though in a more indirect way: The high number of nouns with suffixes in the plural but without any class marking prefixes in the singular would be the result of massive borrowings, which have been per default attributed to this group of nouns. As a consequence the noun class systems of the Baïnounk languages have shifted from predominantly prefixing noun class systems to mixed systems. A discussion of how the mixed system might have evolved and an account of mechanisms for the integration of loanwords into Baïnounk Gubaher in section 5.2 and 6 will support this

\footnotetext{
${ }^{1}$ The number of migrants from Djibonker and their descendants residing in Dakar has been given as around 400. Especially the first generation, who were born and raised in the village, still speak Gubaher, whereas in the subsequent generations it is often the case that the language is neither understood nor spoken.
} 
hypothesis. In section 7 I will present some more instances of contact phenomena involving Baïnounk and surrounding languages concerning the noun class system and also the subject of verbal reduplication. It has to be kept in mind that the research on Baïnounk is still at a starting point and therefore the data and hypotheses used in this paper constitute preliminary results and directions for further research which nevertheless show the potential of even the relatively little data collected so far for contact linguists, theoreticians interested in nominal classification and typologists.

\section{Historical Background and resulting multilingual situation}

Over the last 500 years, invasions and shifts of power have heavily influenced the linguistic landscape of Casamance, which is why a concise historical overview is necessary for a better understanding of today's situation.

Oral tradition and evidence based on scientific research converge on the conclusion that the Baïnounk ${ }^{2}$ were the autochthonous inhabitants of the area, dominating a kingdom of traders, which must have been still powerful, but already declining, at the time of arrival of the Portuguese in the late 16th century, and which finally dissolved completely in the 19th century (Bühnen 1994; Roche 2000). Centuries of conquests, slave trade, population movements and wars led to the breakdown of these structures. Sources from 17th century historical data (Bühnen 1994 and 1992; d'Avezac 1845; Lespinay 1997a) confirm that language(s) closely related to present-day Baïnounk varieties were in use between the River Gambia and the Rio Cacheu, i.e. between modern Gambia and the northern part of Guinea Bissau, at that time. As a consequence of their political decline, the Baïnounk identity, together with language and culture, has today been reduced to marginal remnants in an environment dominated by Mandinka and Joola groups.

The inclusion of 'Baïnounk' ${ }^{3}$ in a multilingual dictionary featuring, among others a Joola variety called Feloupe, Wolof and Saracole is a sign of the importance of Baïnounk as a trading language in the area (D'Avezac 1845). Joola groups had probably already entered the area before the 15th century (Bühnen 1994), first occupying the coastal areas and then moving east into the interior. The Portuguese presence in Casamance and Guinea goes back to the late 16th century, both Ziguinchor and Cacheu (Guinea Bissau) having been founded in 1645 by Portuguese traders. Ziguinchor itself was established on the site of a Baïnounk village and, according to Roche (1976, 2000), the mixed Portuguese-African Creole speaking population descends from original Baïnounk dwellers, captives and the Portuguese population. Although the physical presence and political power of the Portuguese was never very strong - 1,500 inhabitants as late as 1842 - their disruptive influence through slave raids and the resulting conflicts among the local groups was nevertheless marked. The population loss among the Baïnounk to the slave ships was substantial (Rodney 1969) and many died in wars with the Joolas and Balantas. In addition to that, the expansion of the Mandinka kingdom of Gaabu from the east and the Balanta pushing up north from present day Guinea Bissau into Baïnounk land probably also contributed to the collapse of Baïnounk hegemony and political structures. The last episode in this history of conquest and shifting power was marked by the growing influence of the French in the region, starting at the beginning of the 19 th century and culminating in the taking of Ziguinchor from the Portuguese in 1886. As a result of these historical events, Mandinka, Peul, Joola Fogny, French, and Portuguese Creole are still important linguae francae in Casamance, while Balanta, Manjaku, and smaller Joola languages also serve as linguae francae, though on a smaller scale. In addition to these are minority languages such as the varieties of the Bainounk cluster, Bayot etc. Since the

\footnotetext{
${ }^{2}$ No judgement on continuity is intended here, since it is unclear what the cultural identity of the people designated Baïnounk was based on. It is unclear in what relationship this (ethnic?) group stands to the people who nowadays call themselves Baïnounk or are considered as such because of either linguistic or cultural behaviour.

${ }^{3}$ Here, the name Bagnon is used. It is unclear which Baïnounk variety the dictionary features.
} 
country's independence in 1960, Wolof is spreading rapidly as Senegal's national language (Dreyfus and Juillard 2004; McLaughlin 2009). Traces of this changing history can be found throughout the Baïnounk lexicon. Among the various loans in Gubaher we find: from Joola maregen 'correct' and bu-jinum 'mind'; from Portuguese losa (Kriolu losa) 'shop' and kaleroy (Kriolu kaleron) 'pot'; from Mandinka koloy 'well' and sahs 'sheep'; and from French tabl 'table' and bu-wer (French verre) 'glass'.

The ongoing battles in the interests of, simplistically put, colonial power (Portuguese, French), land (Balanta, Joola) and religion (Mandinka, Peul) have caused massive shifts in linguistic and ethnic identities. As shown by Bühnen's (1992) research, many place names found today in Gambia, Casamance and northern Guinea have Baïnounk etymologies. On this basis and the accounts of written and oral sources (see Bühnen 1994), it can safely be assumed that they were originally founded and inhabited by Baïnounk. In the course of history the name-giving Baïnounk population has either been assimilated by the newcomers or driven off their lands (Lespinay 1987 and 1996). In the course of this process, historians and anthropologists strongly suspect that various aspects of Baïnounk culture such as dances, clan names, trading practices, initiation rites and linguistic traits have very probably found their way into their assailants' culture and vice versa (see Lespinay 1997a; Mark 1992; Linares 1992; Bühnen 1994 for an overview of the convergent cultural features of the area). It has to be kept in mind that it is not an easy task to establish the ethnic origin of any cultural item, since the diminishing Baïnounk communities have equally been heavily influenced by the cultures of their more numerous and more dominant neighbours, particularly Mandinka and Joola. Another possibility is that cohabitating communities have shaped cultural practice together and in this way created something new, which sets them apart from the inherited patterns of both sides.

\footnotetext{
The peoples of Lower Casamance and the northeastern Casamance have a long common history; their relations range from migration and intermarriage to commerce, which included the slave trade. Centuries of contact have led to extensive cultural interaction and borrowings. Consequently, many cultural traits have not remained confined to specific areas (Peter Mark 1992: 113).
}

As outlined above, this contact-induced cultural interaction certainly entails extensive linguistic contact between the speakers of the Casamance languages. Again, as a consequence of the changing status as either "giver" or "receiver" between Baïnounk and the culture it has been in contact with, it is yet too early to determine the direction of borrowing or calquing in many cases. It is obvious already at this early stage of investigation that Baïnounk Gubaher does share vocabulary with Joola Kujirerai, Joola Banjal and to a lesser extent with varieties of Bayot. The same holds true for Baïnounk Gunyaamolo, which is in close contact with Joola Fogny and Mandinka.

In fact, multilingualism is so deeply rooted into Baïnounk culture (as encountered in the villages of Djibonker and Niamone (see Lüpke, this volume) that it has become a matter of pride to make oneself understood in as many languages as possible, but at the same time not to be understood by outsiders when speaking the in-group language. In Djibonker, but probably also elsewhere among Baïnounk speakers, it is normal for children to master four languages, and a repertoire of six to ten languages is nothing unusual for an adult person. It becomes clear now that the effects of language contact have to be much more pervasive in such an environment than in a largely monolingual European environment, considering that the place where language contact takes place is the mind of the multilingual speaker. The kind of data collected and the linguistic methods applied will have to be re-evaluated and adapted to the scenario in order to guarantee a proper description of the language.

Although the conditions are close to ideal and first results are very promising there are various problems to be countered when conducting areal research in southern Senegal. First, many languages, their varieties, and even complete language families remain almost or 
completely undescribed until today and even when there are data available, they are in many cases not sufficient for deeper comparative work. Second, even for the larger, national and regional languages (Wolof, Kriolu, Peul, Mandinka) and much more so for the minority languages of Casamance, detailed dictionaries are the exception, etymological research being only at a starting point (Rougé 2004). Third, due to little scientific research having been undertaken, the detailed history of the region, including migrational movements and provenance of populations, is still hardly known. All these factors make it hard to identify loan words in the first place and even harder to establish the direction of borrowing. The items in table (1) serve as an example of how difficult it is to identify the exact donor language of a number of Kriolu words of undoubtedly African origin. For each of the words, a Baïnounk origin is impossible to verify or falsify at this stage of research.

Table 1 : Portuguese Creole (Kriolu) nouns with African origin and their Baïnounk cognates ${ }^{4}$

\begin{tabular}{|l|l|l|l|}
\hline $\begin{array}{l}\text { Baïnounk } \\
\text { Gubaher (Kriolu) }\end{array}$ & English & Etymology & Distribution \\
\hline $\begin{array}{l}\text { mayka:ra } \\
\text { (mankara) }\end{array}$ & peanut & $\begin{array}{l}\text { unclear, possibly from Bijogo } \\
\text { or the Nuun root gu-jankari } \\
\text { 'peanut' }\end{array}$ & $\begin{array}{l}\text { Kriolu of Guinea } \\
\text { Bissau/Casamance and } \\
\text { Cape Verde, also in } \\
\text { Mancanha }\end{array}$ \\
\hline fi-hudi (jugude) & vulture & $\begin{array}{l}\text { possibly Mandinka duga } \\
\text { 'vulture', or Atlantic root, ji- } \\
\text { being frequent for animals in } \\
\text { Baïnounk }\end{array}$ & $\begin{array}{l}\text { similar forms in } \\
\text { Manjaku, Mancanha }\end{array}$ \\
\hline $\begin{array}{l}\text { ba-gec } \\
\text { (bagitx/badjik) }\end{array}$ & oseille & probably Nuun bagec & $\begin{array}{l}\text { Kriolu } \\
\text { Guinea/Casamance of }\end{array}$ \\
\hline $\begin{array}{l}\text { ba-fid (badjuda) } \\
\text { girl }\end{array}$ & young & $\begin{array}{l}\text { probably Nuun bëgid/bajido } \\
\text { etc. }\end{array}$ & $\begin{array}{l}\text { Kriolu of Cape Verde, } \\
\text { Guinea } \\
\text { Bissau/Casamance }\end{array}$ \\
\hline fagas (djagasi) & Atlantic root *jag/x & $\begin{array}{l}\text { occurs in Wolof jaxase } \\
\text { 'mix', nun bu-jagasin } \\
\text { 'put together' }\end{array}$ \\
\hline -bomb (banbu) & $\begin{array}{l}\text { carry on } \\
\text { back }\end{array}$ & unknown & $\begin{array}{l}\text { also occurs in Mankanha/ } \\
\text { Manjaku bamb, } \\
\text { Mandinka bambu with } \\
\text { the same meaning in jaxato, }\end{array}$ \\
\hline bu-faxata (djagatu) & $\begin{array}{l}\text { bitter } \\
\text { aubergine }\end{array}$ & probably Atlantic & $\begin{array}{l}\text { also in Wolof jandinka } \\
\text { Manjaku bë-jakata with } \\
\text { the same meaning }\end{array}$ \\
\hline
\end{tabular}

\footnotetext{
${ }^{4}$ The data concerning etymology and distribution are taken from Rougé (2004). The Baïnounk Gubaher examples are from my fieldnotes. It is not made clear by Rougé (2004) what he means by the label Nyun, if it is a form found in one or more of the modern varieties of Baïnounk/Kobiana or Kasanga or a reconstructed form.
} 


\section{The Baïnounk, their languages and their neighbours}

It is difficult to say with certainty where Baïnounk is still spoken and how many speakers each variety has. The most detailed survey available is in the form of a map compiled by Sauvageot (1973), when some varieties were already dying or extremely vulnerable. Two generations and a decade of civil war later it would be surprising if the situation was still the same. Baïnounk is with certainty still spoken in and around Niamone (see Lüpke, this volume for a detailed description of this speech community), southwest of Bignona and in Tobor. Gunyaamolo (of Niamone) and Gutobor (of Tobor) are often regarded as close dialects of one variety. Gunyaamolo is also spoken in the village Borofay Baïnounk south of Ziguinchor. South of the river we find the southwestern dialects comprising Gubaher in Djibonker, Gubelor in Djibelor and Gufangor in Djifangor, which share phonological and grammatical traits but are nonetheless quite different from each other. Baïnounk Gujaxer is spoken in the area east of Ziguinchor around Gudomp, Niaguis, Adeane etc. and in Guinea Bissau, around São Domingo and close to the Senegalese border in a couple of villages, including Jegui. Most of the Baïnounk languages seem to be only little or not at all mutually understandable, intelligibility often decreasing with growing distance. From my own experience, speakers of Gubaher have great difficulties understanding both Gunyaamolo and Gujaxer if they are not used to hearing it. No exact statement can be made at this point about the Baïnounk languages of the northern and the north-eastern parts of Casamance (the historical regions of Sambu, Sonkodu, Yassine and Boudhie) and southern Gambia (Bühnen 1988; Bühnen 1994:527ff). It seems as though Baïnounk is not spoken anymore in these areas, or maximally remembered only by very old people.

French and Wolof are increasingly spoken and understood everywhere in Senegal, including in Casamance, but the local and regional linguae francae are less evenly distributed. Fortunately for the linguist interested in contact-induced change, the different Baïnounk communities have little contact with each other and also use different sets of contact languages (see figure 1). This could allow the researcher to retrace differences in vocabulary, grammar and phonology to the influence of one or more specific contact languages, provided detailed dictionaries and other materials for dialects are available. 


\section{Figure 1: Baïnounk speaking villages in Basse Casamance (Sauvageot 1973), with present-day dominant regional languages added}

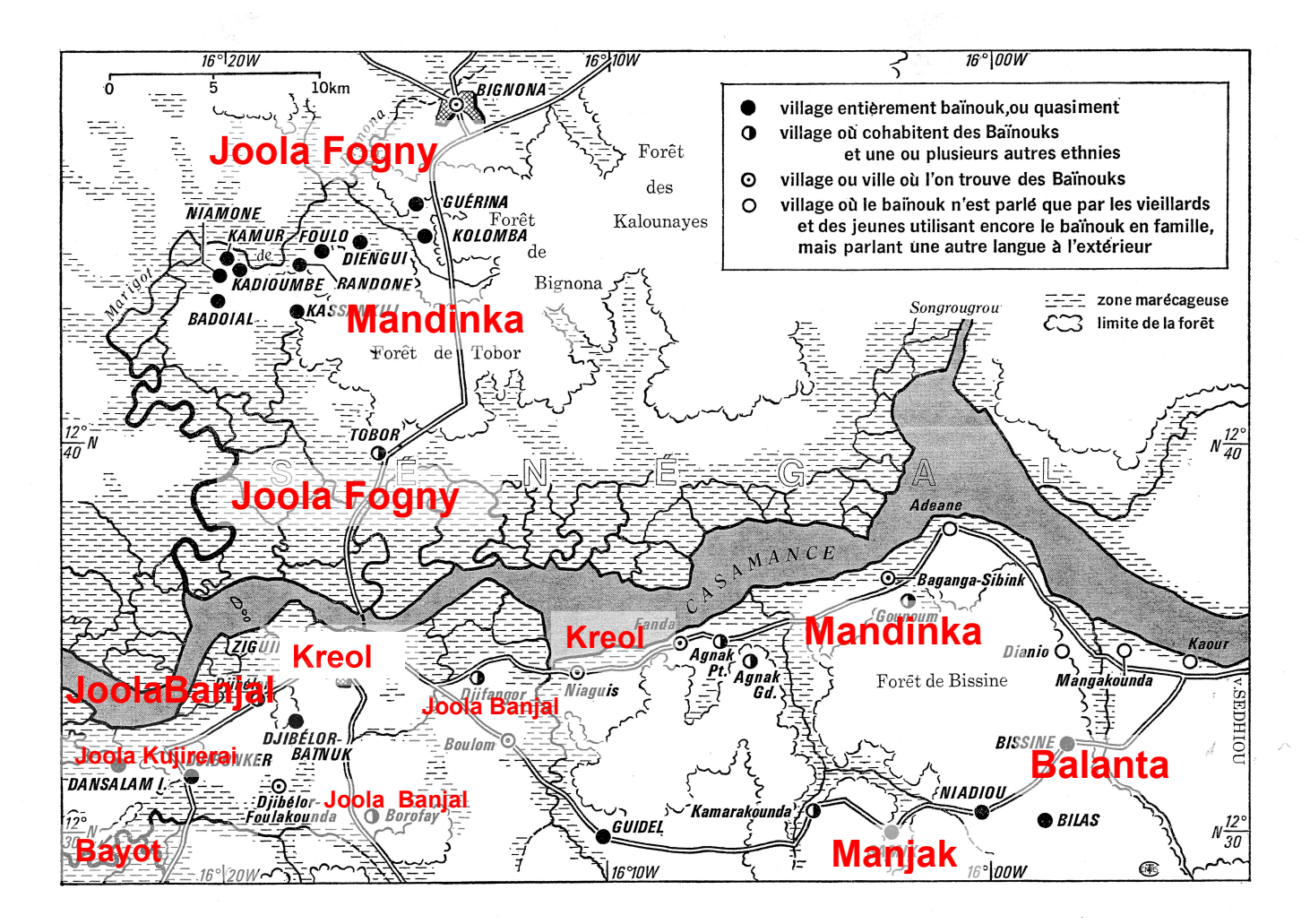

In the case of Baïnounk Gubaher this is not the case; three of the languages spoken by the inhabitants of Djibonker are themselves only poorly described minority languages: Joola Banjal (Sagna 2008; Tendeng 2007; Bassène 2006), Joola Kujirerai (no sources found) and Bayot (Diagne 2009). Family ties, cultural parallels and physical vicinity strongly connect the people of Djibonker to the Joola Banjal of Mof Avvi to the west and the inhabitants of their neighbour village, Brin, where Kujirerai is spoken. Similar but less dense connections seem to exist with the Bayot to the south of Djibonker, around Nyassia and Dioher.

Lespinay (1997a) contends that an identity change from Baïnounk to Joola could take place within few generations (see also Bühnen 1994:642), for this shift has happened in the Fogny area. Oral sources recall that it is frequent for converted and assimilated Baïnounk to change their clan name to a Mandinka one and abandon the Baïnounk language (as happened in the middle Casamance around Sedhiou). On the other hand, Balanta conquerors are said to have adopted their Baïnounk victims' clan names when taking over their villages (confirmed by Bühnen 1994:343 and 160); in this process aspects of Baïnounk culture and language may have stayed alive within a Balanta environment. Indeed, typically Baïnounk clan names such as Manga, Sagna, Mane and Biagui are found among Joola, Mandinka, and Balanta all over the region. A recent example of identity change is found in the village of Brin (Jirer), whose inhabitants remember that their great-grandparents still used to speak Baïnounk. Their Baïnounk ancestry is corroborated by the fact that most villagers bear Baïnounk clan names such as Diandy and Biagui. Although now Joola-peaking, some consider themselves Baïnounk and maintain family ties to other still Baïnounk-speaking villages. The heavy influence of Baïnounk on this Joola variety (known as Kujirerai, Joola Hulon or Kuluunaay) at the lexical level bears witness to the Baïnounk past of the Brinois.

In table (2) I give some examples of cognates which I strongly suspect have been borrowed or retained by Kujirerai from Baïnounk Gubaher. The stems of 'wind', 'wing' and 'ashes', are identified by Doneux (1990) as cognates in Kobiana and Baïnounk and are 
therefore assumed to be part of the inherited vocabulary, while the equivalents in Joola Banjal, the closest relative of Kujirerai, are different. The stem -na:y for the verb 'wash (clothes)' is also attested in Baïnounk Gubelor, Gujaxer, and Gunyaamolo; again, Joola Banjal uses a different stem. Speakers of Gubaher are aware of the lexical parallels between their language and Joola Kujirerai; some even go so far as to say that the latter is a "mix" of Joola Banjal, Joola of Affiniam and Baïnounk Gubaher. Unfortunately, the lack of data on Kujirerai makes it impossible to explore this claim and much less to say anything about syntactic or morphological calques, though these could be expected. Further research in this direction, as a microstudy of how exactly language shift has impacted on the phonology, syntax, morphology and lexicon of this language, would be extremely interesting.

Table 2: Cognates shared by Gubaher and Joola Kujirerai, contrasted with the translational equivalents in Ñun (reconstructed) and Joola Banjal

\begin{tabular}{|c|c|c|c|c|}
\hline Gloss & $\begin{array}{l}\text { Gubaher } \\
\text { (fieldnotes) }\end{array}$ & $\begin{array}{l}\text { Kujirerai } \\
\text { (fieldnotes) }\end{array}$ & $\begin{array}{l}\text { Ñuun } \\
\text { 1990) }\end{array}$ & $\begin{array}{l}\text { Joola Banjal } \\
\text { (Seleki, } \\
\text { fieldnotes) }\end{array}$ \\
\hline 'wind' & $b a-w u c$ & $b a-w u c$ & $* b u-u c$ & orus \\
\hline 'wing' & $g u-b \partial: r$ & $k a-b a: r$ & *gu-bond & $g a-b \varepsilon s$ \\
\hline 'ashes' & $b u-r \partial t$ & bu-rotoy & $*_{-} d V(n) t$ & bu-kugai \\
\hline 'door' & gu-mayga:t & 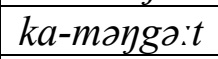 & ${ }^{*}$ gu-bund & ga-negen \\
\hline $\begin{array}{l}\text { 'wash } \\
\text { clothes' }\end{array}$ & bə-nว:7 & bə-nว:7 & $?$ & ba-pos \\
\hline
\end{tabular}

\section{The Baïnounk Gubaher noun class system}

Comparative data on nominal classification in Atlantic languages - especially when compared to the wealth of data on Bantu gender systems - is scarce; to my knowledge only Doneux (1975), Sapir (1971) and Pozdniakov (1993) have made attempts at reconstructions and generalisations concerning the whole phylum. More detailed accounts of noun class systems of the bigger languages of the northern division of the group, Fula, Wolof, and Seerer, are available, but to this point almost nothing can be found on most languages of Casamance, Guinea Bissau and the South Atlantic languages. The noun class systems of the Ñuun languages (this includes Kobiana, Kasanga and all Baïnounk languages) are quite similar to each other (compare Wilson 2007; Lespinay 1997; Sapir 1971; Doneux 1990; Basso Marques 1947), and they have in common that they are certainly among to the most complex gender systems attested in Africa. If, as commonly accepted, the number of agreement markers is used as a defining criterion of a noun class, Baïnounk Gubaher would count well over 30 noun classes. The complexity lies in the combination of at least two different mechanisms of class marking on the noun, occurring in various combinations and with numerous exceptions. The majority of nouns in Baïnounk Gubaher is prefixing, with paired noun class markers for singular and plural. Another large group of nouns does not show any prefixed class markers neither in the singular nor in the plural but marks pluralisation with suffixes. A less numerous group combines the two strategies, using both prefixes and suffixes. Agreement patterns are equally complex. The noun class markers have the form $(\mathrm{C}) \mathrm{V}$, some markers have the allomorph $(\mathrm{C}) \mathrm{VN}$ with specific nouns, $\mathrm{N}$ being a nasal consonant (e.g. $\operatorname{si}-/ \sin$-). The rules governing the allomorphy are still unknown. The noun class and agreement markers containing the vowel 'a' also have an allomorph in ' $\partial$ ' (e.g. $b a$ /bo-) which seems to co-occur regularly with closed ${ }^{5}$ vowels in the stem. Agreement in

\footnotetext{
${ }^{5}$ Further research is needed to establish the rules of vowel harmony in Baïnounk Gubaher.
} 
Baïnounk occurs in the noun phrase on adjectives, numerals and pronouns, but never on verbs. According to Grinevald (2004: 62) a typical noun class systems has the following properties :

Table 3: Typical properties of noun class systems (Grinevald 2004: 62)

\begin{tabular}{|c|c|}
\hline Criteria & Fulfilled in Baïnounk \\
\hline - all nouns have to be classified & Yes \\
\hline - $\quad$ smallish number of classes & No \\
\hline - $\quad$ closed system & $\mathrm{Yes}^{6}$ \\
\hline $\begin{array}{l}\text { - fused with other grammatical } \\
\text { categories (definite marker, number, } \\
\text { case) }\end{array}$ & Partly $^{7}$ \\
\hline - $\quad$ can be marked on noun & Yes \\
\hline - realised in agreement patterns & Yes \\
\hline - noun uniquely assigned to a class & Mostly yes, some variation observable \\
\hline - no variation in register & no information \\
\hline
\end{tabular}

Baïnounk Gubaher does indeed fulfill most of these criteria, though the high number of agreement patterns and the amount of variation observable regarding the class membership of certain nouns, distance the systems as found in Baïnounk from typical noun class systems.

The combination of suffixed and prefixed class markers and agreement markers in one gender system, as observed in Baïnounk might seem peculiar from a typological point of view but is observable in many Atlantic languages. Wolof has postposed noun-marking clitics, Fula has noun class suffixes, Seerer has both prefixes and suffixes, and so have Nalu/Mbulungish and almost all South Atlantic languages, as well as the Nuun languages (see Childs 1983; Sapir 1971; Doneux 1975). McLaughlin's (1997) observations on the Wolof noun class system will be considered when assessing the influence of language contact on nominal classification in Baïnounk (see section 6).

Before investigating the role of contact and discussing Sauvageot's (1967 and 1987) hypotheses regarding the characteristics of the noun class system of Baïnounk Gunyaamolo, I am going to give an overview of Gubaher noun classes and the ways they are marked.

\subsection{Purely prefixed class markers in Gubaher}

The majority of nouns in Gubaher are prefixed with a noun class marker in both singular and plural. Agreement is largely alliterative (Corbett 1991), i.e. the agreement marker is equivalent or phonetically very similar to the class marker itself. Agreement in Gubaher is marked on adjectives, numerals and demonstratives, relative pronouns, interrogative pronouns and other pronouns, but never on verbs.

\footnotetext{
${ }^{6}$ The high number of agreement patterns raises questions concerning to the openness of the system. It might have been open at one point in its history, creating new noun classes for loanwords but synchronically speaking it does not seem as though the adding of noun classes is still productive at this stage. McLaughlin (1997) gives a similar analysis for Wolof, where competing mechanisms of loanword integration succeeded each other in different stage sin the history of the language.

${ }^{7}$ Some markers conflate number and noun class, whereas for some nouns number is expressed through the presence or absence of the plural suffix.
} 
(1) ra-ma:six ran-de CL-crab AGR-big 'big crab.'
(2) na-ma:six na-na:k

CL-crab AGR-two

'two crabs (count plural).'
(3) „a-ma:six „a-ya:n

CL-crab AGR-DEM

'those crabs (collective plural).'

The system is crossed, meaning that nouns of one singular class can combine with more than one plural class and vice versa. Certain combinations of singular and plural class markers are more common than others. Table (4) shows the main singular/plural pairings. Some class markers, and also agreement prefixes, have two allomorphs, a simple one ending in vowel and an alternative form ending with a nasal consonant, e.g. si- and sin- or $r a-$ and $r a n$ - (see ex. $\left.(1)^{8}\right)$. In addition to the first plural, used with countable nouns, many nouns can combine with a second plural, which is a collective plural for non-countable quantities, or non-specified numbers of entities (ex. (3)). The purely prefixed nouns look reminiscent of noun class systems found in the Joola languages. I have counted nine singular noun class prefixes, three of which are very rare, and seven countable plural classes. To these are added four collective plural classes for indefinite masses.

Table 4: Paired, prefixed noun classes in Gubaher

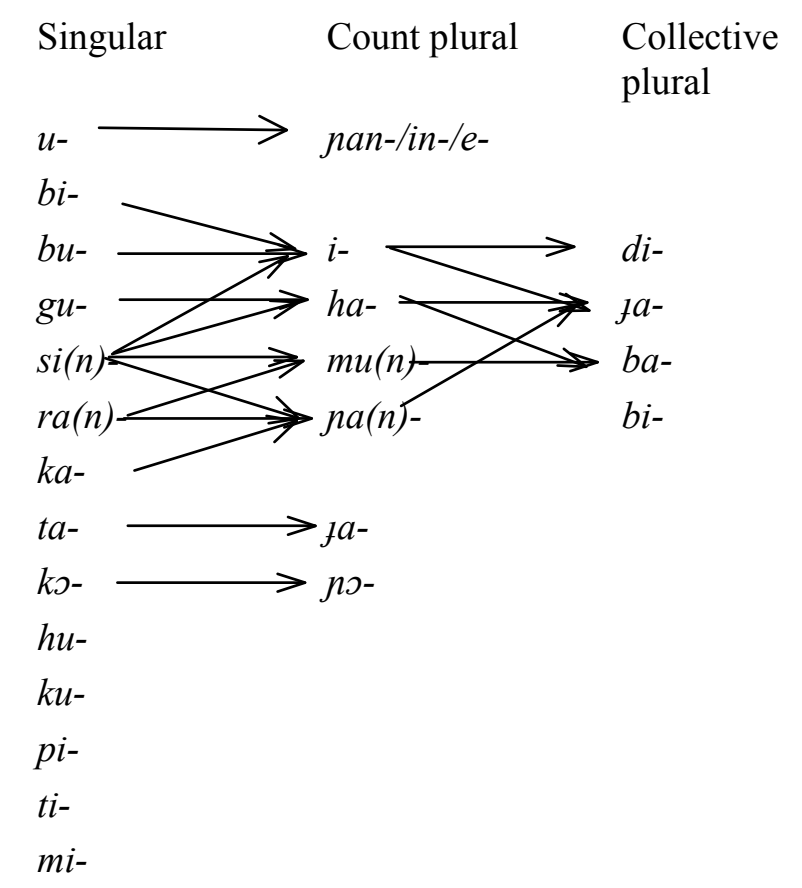

Also part of the system are five non-paired class markers which are extremely rare, so far only observed on one to three items in a lexicon of ca. 1,500-2,000 items (work in progress): hu- (hu-ya:n 'thing'), pi- (pi-t:ari 'tobacco), mi- (mind 'milk), ti- (ti-rux 'cool season, chill') $k u$ - (ku:g 'hunger', kum-pan 'honey', ko:l 'fire'). Agreement is alliterative and prefixed: $t i-r u x$ tin-de 'big chill'.It is unclear in some cases if and how these nouns should be segmented, i.e. if the noun class marker is an independent affix, or not a noun class marker at all but part of the stem; Doneux (1990:19f) uses the term "figé" to refer to similar cases in Kobiana, where the noun class marker has merged/fused with the stem. These nouns do not have plural forms, either because the noun denotes an abstract or a non-countable entity.

\footnotetext{
${ }^{8}$ The occurrence of $\mathrm{CV}$ class markers with the same consonant but different vowels and also the nasal consonant found with some noun class prefixes points to the discussion of the augment in Atlantic languages (see Doneux 1990 \& 1975b; Pozdniakov 2010).
} 
It could be argued, in these cases, that a noun class should by definition cover more than one or two items, but the phenomenon of very unproductive noun classes seems to be typical of Atlantic languages, especially with words denoting culturally salient concepts:

\footnotetext{
Il est faux de penser que chaque appariement de classe nominale, faiblement représenté, refléterait un figement ou la disparition de prefixes ayant existé. Les langues atlantiques se caractérisent par un trait particulier: on y rencontre souvent une classe spéciale ne comportant que deux ou trois noms ou même un seul. [...] Chaque langue atlantique présente au moins un mot ayant un accord statistiquement rare, irrégulier, qui traduit une notion sélectionné et marquée dans cette culture precise (Ferry and Pozdniakov 2001:166).
}

Some of the classes have clear semantic values and/or are used for derivational purposes: $u$ - in the singular and the three plural markers $n a$-, in- and $e$ - are used for human beings; $k s-$ $/ n s-$ are the diminutive classes; $s i-/ m u$ - contain almost all trees and some other plants; $b u-/ i$ $/ d i$ - the majority of fruits; and $b i$ - is the collective plural for insects. More research is required in order to make any statements about the semantic status of the other noun classes.

\subsection{Nouns with default agreement in Gubaher}

The second largest agreement class includes mostly prefixless nouns, which form plurals by suffixing $-V \eta$, the vowel of the suffix being determined by rules of vowel harmony:

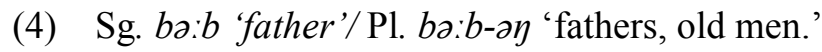

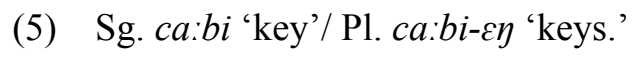

These nouns make up a significant part of the noun inventory of Gunyaamolo: Sauvageot (1967:229) reports their ratio as 200 out of 800 , and 400 out of 1,200 in a more recent paper (Sauvageot 1987:21). Similar proportions are noted for Baïnounk Gubaher. Many loanwords, especially from French, Portuguese, Mandinka, and Wolof, as in example (5) ${ }^{9}$, are found in the default noun class. Dependent elements take the prefix $a$ - in the singular and the prefix $a$ and the suffix $-V \eta$ in the plural (see ex. 6-9)

\section{(6) ko:na a-munduk house AGR-one 'one house.'}
(8) ji-fck a-de
PR-pig AGR-big
'big pig.'

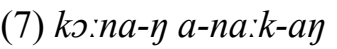 house-PL AGR-two-PL 'two houses.'}

(9) $\jmath i-f \varepsilon k-\varepsilon \eta a-d e-e \eta$ PR-pig-PL AGR-cat-PL 'big pigs.'

The nouns in this group are the Gubaher equivalent of the nouns that Sauvageot (1967, 1987) calls prefixless for Gunyaamolo, but there are criteria that indicate that some nouns demanding default agreement do actually have prefixes in Gubaher (see ex. 8 and 9). This is often the case with nouns beginning with $a$ - or $f i$-: these nouns do not have their own patterns of agreement markers which would establish them as independent noun classes, but in some cases, the prefix $a$ - or $j i$ - can be substituted by the diminutive or augmentative prefix (as in (10)), evidence for the fact that they are not part of the noun stem but segmentable affixes. It seems that in Gunyaamolo, the markers in question have fused more with the stem, since they cannot be substituted by derivational prefixes in the cases reported by Sauvageot.

(10) $j i-f \varepsilon k$ 'pig', $j i-f \varepsilon k-\varepsilon \eta$ 'pigs', $k \supset-f \varepsilon k$ 'little pig.'

${ }^{9} c a: b i$ 'key' goes back to Portugese chave/ Kriolu cabi. It might have been borrowed directly from either of the two or through another African language, e.g. from Wolof which also has ca:bi 'key'. 
In other cases though (see (11)), nouns do not substitute the putative class marker with the derivational class marker, but stack them onto the stem containing $j i-$.

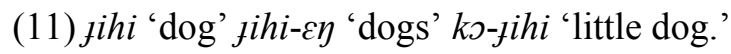

Since agreement is the main criterion for class membership it might be safer to use the label "default group" for these nouns, irrespective of the morphological evidence for or against independent prefixes on the noun itself.

\subsection{Mixed agreement group in Gubaher}

A third group of nouns combines characteristics of the prefixed and the default group. Singular agreement is prefixed and alliterative, like that of the purely prefixed nouns, whereas plural agreement is both prefixed and suffixed.

(12) $b ə-k a r b a-m-b a$

CL-chicken AGR-DEM-AGR

'this chicken.'

(14) fe:bi fa-dika:m

goat AGR-female

'female goat.'

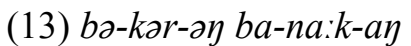

CL-chicken-PL AGR-two-PL

'two chickens.'

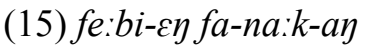

goat-PL AGR-two-PL

'two goats.'

The mixed agreement nouns can be divided into two subclasses: those which use the same prefix in singular and plural on the noun and in agreement (see (12) - (15)), and those which take the prefix $a$-in the plural combined with the suffix $-\mathrm{Vy}$ irrespective of the class marking prefix in the singular (e.g. Sg. bu-ks:r, Pl. a-ks:r-sy 'village'). Most of the prefixes observable in the mixed agreement class do not occur as singular prefixes in the paired prefixed groups or if so then only very rarely.

As is the case with some nouns in the default group (as shown in (10) and (11)), the mixed agreement nouns do not behave uniformly as to whether the prefix is an independent morpheme or fused with the stem. I will make this clear by showing the behaviour of mixed agreement nouns when they are derived with the diminutive suffix Sg. $k o-/ \mathrm{Pl}$. no-. The diminutive forms of some of these nouns substitute the first syllable for the diminutive marker (see (16) and (17), which are the diminutive forms of bo-kər as in (12) and (13)). This means that in this case the noun class marker bo- is not a part of the stem since it can be substituted by another prefix.

(16) $k J-k a r$

DIM:SG-chicken

'small chicken.'
(17) $n \jmath-k a r$

DIM:PL-chicken

'small chickens.'

In other cases though, the diminutive is prefixed to the complete noun, as in examples (18) and (19), the diminutives of $f e: b i$ 'goat' of example (14) and (15). We have to assume that the noun class marker $f a$ - has fused with the stem and is not separable from it.
(18) ko-fe:bi
DIM:SG-goat
'small goat.'
(19) $n \supset-f e: b i$
DIM:PL-goat
'small goats.'

Again, some classes have so far only been recorded with one or two nouns exhibiting the mixed agreement pattern, this includes the noun classes with the singular prefixes $h o-, b u$ - and $\mathrm{f}^{-}$. 
Table 5 : Mixed agreement nouns in Gubaher

\begin{tabular}{|l|l|l|l|}
\hline $\begin{array}{l}\text { Class marker } \\
\text { prefixed or } \\
\text { inseparable) }\end{array}$ & $\begin{array}{l}\text { Agreement } \\
\text { marker }\end{array}$ & Plural & $\begin{array}{l}\text { Plural } \\
\text { agreement }\end{array}$ \\
\hline$k a-$ & $k a-$ & $k a--V \eta$ & $k a--V \eta$ \\
\hline$t a-$ & $t a-$ & $k a--V \eta$ & $k a--V \eta$ \\
\hline$f a-$ & $f a-$ & $f a--V \eta$ & $f a--V \eta$ \\
\hline$b a-$ & $b a-$ & $b a--V \eta$ & $b a--V \eta$ \\
\hline$f u-$ & $f u-$ & $f u--V \eta$ & $f u--V \eta$ \\
\hline$h o-$ & $h o-$ & $h o--V \eta$ & $h o--V \eta$ \\
\hline fa- & $\jmath a-$ & $\jmath a--V \eta$ & $\jmath a--V \eta$ \\
\hline$b i-$ & $b i-$ & $a--V \eta$ & $a--V \eta$ \\
\hline$b u-$ & $b u-$ & $a--V \eta$ & $a--V \eta$ \\
\hline$d a-$ (augmentative) & $d a-$ & $d i n--V \eta$ & $d i n-V \eta$ \\
\hline
\end{tabular}

\section{Contact and litteral alliterative concord (LAC) in Baïnounk Gubaher and Gunyaamolo}

Sauvageot $(1967,1987)$ has expressed two hypotheses about the noun class system of Baïnounk that I will comment on in this paper:

Firstly, the plural suffixes found in Gunyaamolo, and in all other Baïnounk languages, are borrowed from Mandinka. This Mande language has a plural suffix, but no gender system, and is a language from which especially the northern Baïnounk languages have extensively borrowed.

Secondly, the Baïnounk nouns that have both prefixes and suffixes in their agreement patterns are predominantly loanwords and the agreement prefix is a copy of the first syllable of the noun. In this paper I have presented these nouns as a mixed agreement group, in section 4.3. However, on the basis of recently gathered data from other Baïnounk varieties (Gubaher, Gujaaxer, Gubelor) both hypotheses seem implausible. The noun class systems of Gunyaamolo and Gubaher are similar enough to justify the inclusion of material from both languages in this section.

The first hypothesis - a borrowed plural suffix - is hard to maintain in light of the fact that suffixed plurals have arisen internally in many Atlantic languages, and more so if we consider that plural suffixes occur in all Nuun languages, which presumably were already independent languages by the time of the first contact with Mandinka. The evolution of plural suffixes, however, must have occurred before the languages of the Nuun group developed into the different languages and varieties. Otherwise it would be hard to explain how plural suffixes of a similar phonetic shape on the same noun stems arose independently through contact with Mandinka in each of the Ñun languages, especially since we cannot even assume that the southern varieties have had the same intense contact with Mandinka as the northern varieties. Furthermore, the Mandinka plural suffix $-l u$ does not even have formal similarity with the Baïnounk Gubaher and Guunyaamolo plural suffix $-V y$ or the Kobiana plural suffix $-a$.

As to Sauvageot's second proposal, a short introduction of the hypothesis will be necessary at this point before providing the arguments against it. The seemingly irregular agreement patterns of some nouns (see (20) and (21)) and the large number of only marginally attested noun classes and their corresponding agreement patterns have also been the trigger for a theoretical dispute on the relationship between phonology and syntax between Dobrin (1995, 1998), Dimitriadis (1997) and Aronoff (1997). The debate is based on 
Sauvageot's (1967:232, 1987:19) claim that the pluralisation of these nouns involves copying of the first syllable, which is then used as agreement marker on all targets. This implies that ${ }_{j} a$ - in (20) and $k a$ - in (21) are analysed as part of the noun stem and not as noun class prefixes.

(20) łapэn-s ja-wuri

herb -DET CL-long

'the long herb.'

Guñaamolo, (Sauvageot 1967: 232)

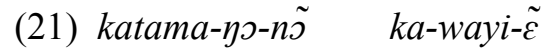

river- DET-PL CL-big-PL

'the big rivers.'

Guñaamolo, (Sauvageot 1967: 232)

If this analysis was correct the number of agreement markers (and ultimately, noun classes) in Baïnounk would have to be expanded to all possible Consonant-Vowel combinations found initially in noun stems, and even beyond that, with the introduction of new initial syllables found in loanwords, resulting in a potentially open number of noun classes. Dobrin (1995:127) has baptised this strategy "literal alliterative concord" (LAC), Dimitriadis (1997:3) prefers the term "productive alliteral agreement. Such a system would be typologically almost unique among the languages of the world; the only other evidence of purely literal alliterative concord, cited by Dobrin (1998), comes from the Papuan language Abuq.

Dobrin argues that LAC is a violation of the Principle of Phonology-Free Syntax (PPFS), which states that syntax has no direct access to phonology without going through the intermediate level of morphosyntax (see Zwicky and Pullum 1986). This implies that syntax can only access morphological categories of a noun, like gender, in order to determine agreement, but cannot directly access the phonological form of the noun. On the other hand, phonology can determine gender membership, but not a syntactic process like agreement.

Dobrin contends that the Bainounk case represents a violation of this principle, since the phonological form of a noun determines the syntactic feature of agreement on dependent elements, without going through any morphosyntactic categorisation. Dimitriadis (1997) recognises the claim that in Bainounk phonological material of the noun is actually copied onto the target as agreement marker, but does not accept this as a violation of the PPFS. She argues that the copied agreement marker is actually a truncated copy of the whole noun (Dimitriadis 1997:16). In this view, the concrete phonological material of the noun is irrelevant to syntax and the PPFS remains intact.

Aronoff (1997) is not so much concerned with the validity of the PPFS, which he sees as a powerful but not necessarily inviolable restriction. In his view LAC represents the unmarked default option of agreement, in its purest form. The reason why it is so rarely found being that

\footnotetext{
[a]ctual phonological copying only emerges when it is forced to, through the rare phenomenon of alliterative agreement [italic in original], because for some reason there is no gender available [...] (Aronoff 1997: 9).
}

The data recently collected on different Baïnounk languages now makes it possible to review these hypotheses critically; in the following section I will present evidence against LAC.

\subsection{Arguments against $L A C$ from Baïnounk Gubaher}

Single examples of prefix copying are indeed attested for Baïnounk, and also for the closely related Kobiana (see Doneux 1990:28 and exemple (25) and (26)), though neither as the dominant strategy nor under the conditions laid out by Sauvageot and subsequently by Dobrin and Dimitriadis. The theoretical discussions surrounding Baïnounk noun classification 
are led without consideration of the fact that the languages presumably exhibiting it, i.e. the varieties of Baïnounk, have so far remained almost undescribed. As a consequence, the debate has revolved around a very limited set of examples provided by Sauvageot $(1967,1987)$. If the copying theory was correct, we should find a large number of phonologically different agreement markers, corresponding to the initial syllables of all possible noun stems attested in Gubaher.

More detailed data from Baïnounk Gubaher do not corroborate this expectation: the prefixes that might have been interpreted by Sauvageot as copied elements add up to less than 15 different prefixes and agreement patterns. Of these 15, roughly 10 show the mixed prefix suffix pattern (as presented in section 4.3) and the remaining 5 are examples of very rare noun class prefixes denoting abstracta or uncountable entities and therefore not occurring in singular-plural pairs (as presented in section 4.1). Caution has to be taken not to view the Baïnounk system in isolation, but to also consider data from related languages and trends in the evolution of their respective noun class systems.

The following points illustrate that agreement of the mixed agreement class of nouns in Gubaher - and also in Gunyaamolo according to the preliminary evidence - is conditioned by morphosyntactic and semantic factors, rather than by phonological ones:

1. Only first syllables containing the vowels $[a]$, $[i]$, and $[u]$ are "copied", i.e. they occur in mixed prefixal/suffixal agreement. Systematically, noun class prefixes in Baïnounk Gubaher and Gunyaamolo, some rare exceptions like the diminutive prefix notwithstanding, display the same distribution of vowels. This does raise suspicions about the pure phonological bases of LAC and suggests that there are some traces of prefixation present in the nouns.

2. Some of the allegedly copied agreement markers are also attested as, although rare, paired noun class prefixes in other Baïnounk varieties. If we look at the examples provided by Sauvageot for Gunyaamolo as evidence for agreement copying and repeated in this paper in (20) and (21), we find that $f a$ - as in fapon-o 'grass' occurs as a regular collective plural prefix in both Gubaher and Gunyaamolo and also as a count plural and even as a singular prefix in Gubaher. The noun class marker $k a$ - as in ka-ta:ma 'river' figures as a noun class prefix in Gubaher (see ex. (25) and (26) and section 7.2) and is also attested in Kobiana (Doneux 1990:27). Another piece of evidence for the affix status of a noun class marker lies in the history of the loanword $f a-f a m e n / p l$. fa-yamen- $\varepsilon y$ 'goat' in Gunyaamolo, cited as a prefixless noun by Sauvageot (1967:229). It can hardly be claimed that $f a$ - is not an independent noun class prefix but part of the stem, when considering that the item is borrowed from Joola Fogny e-jamen 'goat'. Where then does the additional $f a$-come from? The answer becomes evident when we look at the other Baïnounk languages, where the noun for goat is 'feebi' which is in agreement class $f a$-. Apparently in Gunyaamolo the stem -famen has been borrowed from Joola while the noun class $f a$ has been retained from the former feebi. When discussing this lexical item with Gunyaamolo speakers in Niamone and providing them with the Gubaher word feebi, some elder speakers remembered the word as having been in use in Gunyaamolo as well (Friederike Lüpke, p.c.). This proves that the disputed elements do not simply constitute the first syllable of the noun stem but are archaic noun class morphemes in different stages of fusion with the stem. Some of them still behave like segmentable noun class markers in that they can in some cases be substituted by a diminutive or augmentative prefix when the noun combines with a derivative noun class marker. I have presented examples for this in (16)-(19) and (10) and (11).

3. Some of the copied segments are also attested as minor noun classes in the related language Kobiana, where they are treated by Doneux (1990:20f) as fused/fossilised noun class prefixes. It follows that the nouns most probably are not loan words but in fact part of the lexicon inherited from Ñuun. It is awkward to explain why "copying 
of agreement markers" in Baïnounk should occur with non-loans, whereas the majority of recognisable loans are assigned to the default class. If LAC was in fact a productive process in modern Baïnounk, we would rather expect it to be applicable to recently acquired loanwords instead. This strategy does not seem to be productive at all though, as no recently acquired borrowed nouns from French, Wolof or Kriolu have been found so far in the mixed agreement group. These loans are usually assigned to the default class or in some cases to one of the prefixed paired noun classes (see section 6).

4. The majority of nouns with mixed agreement refer to animate entities (family members, plurals of first names, animals), a semantic bias which again speaks against purely phonological copying. We find many denotations for family members, proper names, and animals in the groups of nouns which have suffixed plural: the most important domestic animals, all insects, many fish and birds, all animals that start with $a$ - and $j i$-.

All these findings suggest that the hypothesis of direct access to phonological material by syntactic processes cannot be confirmed, and that contact plays no role in the emergence of suffixed agreement markers in the way Sauvageot has proposed.

\subsection{Alternative scenarios for the development of the mixed Gubaher noun class system}

In the light of the evidence presented above, compounded by the fact that this Baïnounk variety is not in direct contact with Mandinka, it does seem implausible that the suffixed plurals of Baïnounk Gubaher are borrowed from a Mande language, and that copying of the first syllable of the noun onto agreeing elements is a strategy for incorporating loanwords into the noun class system.

Childs (1983) proposes a scenario for the development of plural suffixes in South Atlantic in several steps which involves animacy as the triggering factor. In the absence of historical data Childs assumes that the differences in the distribution of plural suffixes across the languages in question reflect stages in a historical process. The point of departure seems to be animate nouns from which suffixation has spread. At one end of the spectrum we have Temne, where only animate nouns have plural suffixes; on the other end Kisi, where all noun class prefixes have been replaced with suffixes. Childs suggests that

\footnotetext{
[t]wo general processes are at work. The first is the erosion of the functional importance and the phonetic substance of the prefix. The second is the spread of the importance of the suffix, expanding its domain from animate nouns, to plural nouns, to all nouns (Childs 1983:27).
}

These two processes are clearly observable in Baïnounk Gubaher on a synchronic level. The erosion of the functional importance of the noun class prefix is exemplified by the merge of prefixes $j i$ - and $a$ - into the default class. As a consequence these former noun class markers lose their function as such and also their phonetic substance by fusing with the stem in some cases or simply disappearing. The same can be said for other (former) noun class markers which have lost functional importance and fused with the stem, as e.g. $f a$ - in feebi 'goat' and facir 'monkey'. The respective diminutive forms $k o-f e: b i$ and $k o-f a c i r$, where $f$-/fa-cannot be substituted by the diminutive prefix $k o$-, demonstrate the fusion. As for the spread of the plural suffix, the assumption that animacy is a trigger for the spreading of plural suffixation seems plausible for Baïnounk and is compatible with the data. It is of course too early to present an alternative watertight hypothesis as to how suffixed plurals in Baïnounk ${ }^{10}$ have

\footnotetext{
${ }^{10}$ Despite all differences in lexicon and morphology observable between the Baïnounk languages, the noun class systems, at least of Gubaher, Gubelor, Gunyaamolo and Gujaaxet, seem to be surprisingly
} 
arisen and how these suffixes have spread, but I would like to suggest that the plural suffix $-V \eta$ might have originally served as a plural marker for human/animate nouns. This hypothesis is supported by the high concentration of animate nouns in this category. In a list of 152 animal names, 103 or roughly $68 \%$ have suffixed plurals whereas the ratio in a semantically unbiased list would be expected at a much lower rate, around $30-40 \%$. Basso Marques (1947:882) also observes for the related languages Kobiana and Kasanga that the prefixed classes contain mainly animals.

Though at this stage of research it is too early to make a statement about historical processes having shaped the noun class system of the Nuun languages, the following three steps can indeed be observed synchronically, either within Baïnounk Gubaher itself or in comparing different varieties of Baïnounk:

1. Substitution of the original plural prefix with the plural suffix (if we assume that the system has been at one point at least predominantly prefixing).

2. Erosion of the noun class marker or fusion with the noun stem.

3. Loss of original agreement patterns and shift to default agreement.

In this scenario the Baïnounk nouns with the prefix $a$ - or $j i$ - have completed this development, since they have in many cases lost their prefix status, their prefixed plural classes and their distinguishing agreement patterns. ${ }^{11}$ The nouns of the mixed agreement group (see section 4.3) have only completed the first two steps: they have lost their plurals and their status as independent morphemes in some cases but retained their agreement patterns. Further erosion of the noun class marker and loss of agreement would in a next step lead to the shift of these nouns from mixed agreement patterns to default agreement. This scenario is corroborated by two observations. First, I noticed that younger speakers in Djibonker, who may be unfamiliar with some of the less basic vocabulary, tend to assign items from the classes with mixed agreement to the default class instead, in this example the

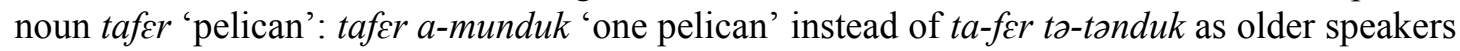
would say. The second observation concerns the north-eastern moribund varieties of Baïnounk, where the shift in three steps described above has been completed for the majority of nouns and plural suffixation seems to have spread to encompass almost all nouns. Bühnen (1988) for north-eastern Baïnounk ${ }^{12}$ gives bunin-o ${ }^{13} /$ bunin-oy-o 'egg' and sian-o/ sian-o-yo 'medicine'. Unfortunately the data available is restricted to one short wordlist without detailed information about agreement patterns and only a few plural forms. Still, the cited examples are significant, since both $b u$ - and $s i$ - never occur with suffixed plurals in Gubaher, but - with one exception each - always as paired prefixed nouns. The equivalents in Gubaher belong to the paired and prefixed group of nouns: bu-ni:n/i-ni:n 'egg' and si-han/mu-han 'medicine. In the northern areas, Baïnounk has been completely substituted by Mandinka in all domains and is only remembered by old people (Moustapha Sall p.c.) Incorrect learning or imprecise remembering due to infrequent usage has probably accelerated the deterioration of the noun class system in these varieties.

We cannot yet explain how the plural suffixes developed in the first place, nor why plural suffixation has become the dominant mechanism for loanword assignment in Baïnounk Gubaher and Baïnounk Gunyaamolo, but the synchronic observations presented above suggest that the three broad agreement groups (prefixed, mixed, default) can be understood as

similar in character so that the observations made on the example of Gubaher should in principle be relevant for the other varieties.

${ }^{11}$ In Kobiana $a$ - is a paired noun class prefix, combining with the prefix ge- in plural (Doneux 1990)., which is not attested in any Baïnounk language known to me.

${ }^{12}$ The Baïnounk language of the historical regions Kamakura, Velingara and Kansambu situated in southern Gambia/north-eastern Casamance.

${ }^{13}$ The final $-o$ is probably a definite marker. This is not clear from the source but highly probable since - o has that function in Baïnounk Gunyaamoolo. 
stages nouns can go through. The impact of language contact lies in the fact that the integration of large numbers of nouns from French, Wolof and Kriolu into the default class has changed the balance of the system, which has been predominantly prefixing, to a system where, due to the large amount of prefixless loanwords, suffixation has become almost equally dominant. In the following section I will concentrate on the competing mechanisms for class assignment of loanwords and further comment on the influence of borrowing on the spreading of plural suffixation in Baïnounk Gubaher.

\section{The integration of loanwords into Baïnounk}

The assignment of prefixless loanwords into the default assignment group with suffixed plurals constitutes a marked influence on the development of the Baïnounk noun class systems. Already a big part of the lexicon consists of classless nouns and if this development continues, Baïnounk might end up losing the noun class prefixes altogether without replacing them with suffixes. McLaughlin (1997) uses Wolof as an example to show how heavy borrowing from other languages has shaped its noun class system. Unlike in Fula and Seerer, the disappearance of the former prefixes in Wolof has not resulted in the emergence of a new set of class suffixes. Without any open class marking on the noun itself the system became more susceptible for change. McLaughlin characterises the Wolof noun class system as hybrid and exhibiting high rates of variation, with conflicting mechanisms of class assignment for loanwords operating parallel to each other. One of the consequences of the integration of loanwords, the majority of them from French, is the growth of the default class $b i$, which, especially in urban varieties, is on the way of becoming the only noun class used with all nouns. The question McLaughlin raises is whether the noun class system of Wolof, or for that matter any noun class system, has ever been in a "perfect" state, i.e. a state before hybridisation and variation occurred. The same could, and should, be asked for the Bainnounk languages with their hybrid systems and the amount of variation observed. It is probable that language contact and the resulting high amount of loanwords exert a heavy influence on the Baïnounk noun class system through the preference of one or the other assignment strategy which can change the characteristics and shape of the whole system. Let us first review the strategies used for the integration of loanwords into the noun class system of Bainnounk Gubaher, including supporting evidence from Gunyaamolo where indicated.

\subsection{Non-prefixed nouns with default agreement in Gubaher}

It seems that the majority of loan words end up as non-prefixed nouns with plural suffixes and default agreement (see section 4.2). The size and productivity of the default class may be a result of the presence of numerous loanwords from non-noun class languages which have been incorporated into Baïnounk Gubaher, as in the case of ca:bi 'key':

\section{(22) ca:bi a-munduk key AGR-one 'one key.'}

\subsection{Semantic assignment}

Loans entering Gubaher can be integrated into the noun class system according to the semantic field they belong to. Whereas for most noun classes, semantic patterns could not yet be identified, the semantic association of noun class $b u-(\mathrm{Sg}) / i-.(\mathrm{Pl}$.) with fruits and vegetables and of the corresponding trees with class si- (Sg.)/ mu- (Pl.) is very robust. Accordingly we find borrowed fruit designations and the trees that carry them assigned to these noun classes:

\section{(24) -limo 'orange' (from Kriolu: limon 'orange')}
a) bu-limo 'orange'
b) i-limo 'oranges'

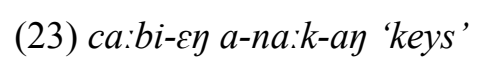

key-PL AGR-two-PL

'two keys.' 
c) si-limo 'orange tree'

d) mu-limo 'orange trees.'

An interesting case from Baïnounk Gunyaamolo is sin-fil/ pl. nan-fil 'electric cable' borrowed from French fil 'thread, cable'. The assignment to class $s i$ - seems to be based on an analogy with sin-kind/ pl. nan-kind 'thread'.

\subsection{Phonological assignment}

In rare cases the first syllable of a loanword gets reanalysed as an existing noun class marker ${ }^{14}$ and integrated into the class of paired, prefixed nouns. Since $k a$ - is attested in Gubaher as a noun class marker (see also section 7.2), it has in (25) and (26) been reanalysed as a noun class marker and separated from the rest of the noun stem. Kriolu is not a noun class language and the first syllable $k a$ is therefore definitely part of the stem in the source language.

(25) ka-leron/na-lerəy 'cauldron/s' > Kriolu 'kaleron'

(26) ka-ra:fa/na-ra:fa 'bottle/s' > Kriolu 'karafa.'

Both nouns are in the agreement class $k a-/ n a-$ and the only nouns so far detected where the prefixed noun class marker $k a$ - in the singular corresponds to a prefixed noun class marker in the plural (in this case $n a-$ ) instead of taking the plural suffix $-V \eta$.

\subsection{Assignment to the most common paired, prefixed noun classes}

In Gubaher $b u$ - and $g u$ - are the most frequent noun classes for objects and do also accommodate some loanwords:

(27) $b u$-wer/i-jer 'glass/es' > fr. 'verre'

(28) gu-furfet/ha-furfet 'fork/s' > fr. 'fourchette.'

Examples (22)-(28) show that the hybridity and variation observed by McLaughlin (1997) concerning the noun class system of Wolof are also characteristic of the noun class system of Baïnounk. Class $b i$ - especially shows high grades of inter-speaker and also intra-speaker variation; in (29)-(31) we see that the noun bi-han 'pot' (29) is by some speakers pluralised with the prefix $i$ - (30), whereas others use plural prefix and suffix with mixed agreement (31). This shows well two of the competing mechanisms in competition: paired classes with paired agreement, and mixed noun classes with mixed agreement patterns.
(29) bi-han bi-de
CL-pot AGR-big
(30) i-han i-na:k
CL-pot AGR-two
'big pot.'
'two pots.'

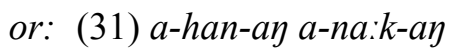
CL-pot-PL AGR-two-PL
'two pots.'

Other nouns with the singular class prefix bi- show the same variation as bi-han: some speakers use only one of the two alternatives but accept the other as grammatical, while some speakers use both alternatives in free variation. In Baïnounk as well as in Wolof a default class is expanding through heavy borrowing and spreading at the expense of other noun classes, which might potentially lead to a stage where the default class will be the only remaining paradigm if the trend is not reversed. All nouns would then exhibit default agreement and mark plurals with the suffix $-V \eta$. The examples from northeastern Baïnounk

\footnotetext{
${ }^{14}$ Doneux (1990:28) mentions a degree of productivity for Kobiana but does not count percentages and gives only one example: Kriolu 'kamisa' > kamisa kaa 'this shirt'.
} 
cited in section 5.2 (bunin-o/bunin-on-o 'egg' and sian-o/ sian-o-yo 'medicine') show that such a development is indeed observable in some of the Baïnounk varieties.

The point though is not to make prophesies about the future of the Baïnounk noun class system but to show how the preference of one noun class assignment mechanism can favour certain developments. The integration of prefixless and suffixed loanwords into Baïnounk Gubaher might tip the balance in the direction of the loss of prefixes and the shift to suffixed plural and default agreement.

\section{Examples of contact induced influence involving Baïnounk Gubaher}

Language contact has certainly had an impact on the noun class system of Baïnounk, but probably not in the way assumed by Sauvageot $(1967,1987)$. I have showed so far that whereas the development of plural suffixes can be more plausibly explained through internal development than through language contact, the development of suffixed plurals as the default option for the integration of loans has certainly influenced the noun class system of Baïnounk. In this section examples of instances where borrowing has had a direct impact on the languages involved will be discussed. Again, the influence goes both ways: from different Joola languages to Baïnounk (7.2) and vice versa (7.1). Not much is yet known about how exactly the noun class systems of Joola and Baïnounk have influenced each other, though high rates of borrowing or calquing are hinted at in the literature; regarding the similarities between Baïnounk and Joola Lespinay goes so far as to claim that
[...] le gusilay ${ }^{15}$ [sic] est aujourd'hui un parler joola mais fortement imprégné de baynunk (syntaxe et système de classe compris), à un tel point que l'on ne peut plus parler d'emprunts mais d'un parler baynunk original en voie d'assimilation (de Lespinay 1997a: 207).

Unfortunately no further evidence for this strong claim is quoted, though further research in this direction will certainly prove rewarding.

In addition to the examples surrounding the noun class system an example of possible syntactic calquing concerning verbal reduplication will serve to complete the picture (section 7.3).

\subsection{Areal diffusion of noun classes: class ji-in Joola Banjal and Baïnounk Gubaher}

Baïnounk Gubaher and Joola Banjal, speakers of which live in close vicinity to each other, do share a great many cultural characteristics (in the domains of agriculture, architecture and religion) and apparently also an important portion of vocabulary. Of these shared lexical items, one case is particularly interesting, the noun 'panther', figaf in Gubaher and fi-g:af in Joola. In Joola Banjal the noun class $j i$ - is a derivational class for diminutives, which seems odd because panthers do not quite seem to belong to the category of sparrows, calves and the other animate occupants of this class. Sagna (2008:256) proposes the explanation that the danger emanating from the wild animal is downplayed in order to tame it figuratively and thus diminish its power, in order to account for its appearance in the diminutive class. This analysis is certainly plausible but the picture becomes broader once we consider data from Baïnounk Gubaher, spoken in the close neighbourhood and tied to the Banjal speaking area of Mof Avvi (comprising the villages of Essil, Seleki, Enampor etc.) through strong links of intermarriage, personal interaction and cultural parallels. There is strong evidence that points to a borrowing of a Baïnounk word into Joola Banjal: Doneux (1990) considers the item as of Ñuun origin, figaf occurs in the same form in Gubaher, Gujaaxer (recorded in Jegui, Guinea Bissau) and also in Kobiana as 'jiya:z' (Doneux 1990), whereas other varieties of Joola use csamai (from Joola Fogny) or cognate forms: csa:me in Bayot Ehing (field notes), ita:me in

\footnotetext{
${ }^{15}$ It is not clear exactly which variety Lespinay is referring to. Gusilay is in some sources used to refer to the dialect of Affiniam (also Joola Buluf), sometimes the dialect of Mof Avvi (Joola Banjal or Gujjolay Eegima) and the dialect of Brin (Kujirerai or Kuluunaay).
} 
Bayot Kugere (Diagne 2009), and asa:mai in Joola Kaasa (variety of Oussouye, field notes). Interestingly, informants from Djibonker have insinuated that jigay has been in use in the Joola Kaasa area as well and was only recently substituted by the Fogny term. Again, a lack of detailed data makes it impossible to tell whether esamai is an innovation spreading from the prestigious Fogny spoken north of the river to the Joola varieties south of the river (Joola Kaasa and Bayot). As mentioned above (section 5.2), the prefix $j i$ - is very common in all Baïnounk languages in connection with animal designations e.g. $j i-f_{\varepsilon} k$ 'pig' in Gubaher, Gunyaamolo and Gujaxer. Apart from the at first glance inappropriate membership of the diminutive class, fig:af also behaves irregularly in Joola Banjal concerning agreement and pluralisation. Instead of entering the diminutive plural class $m u$-, which is usually paired with the agreement class $j u-/ j i-$, the plural of this noun is $s i-g: a\}$, some speakers even accept the singular form jig:aj as a plural. Furthermore, agreement is class $e$ - for the singular and class $s u$ - for plural. The constellation $j i$-/su- is remarkable in that it is exceptional for $s u$ - plurals to be combined with a singular noun class other than $e$ -

Though the noun class marker $f i$ - might have been retained in Joola Banjal for semantic reasons, i.e. the minimisation strategy proposed by Sagna (2008), a consideration of the areal situation and the close contact between Banjal and Djibonker makes it more probable that 'panther' ended up in the Joola Banjal diminutive class not for semantic, but for phonological reasons, since the prefix of the Gubaher loanword is identical to the Joola Banjal diminutive noun class. The borrowing of the item from Baïnounk has disrupted the uniformity of the Joola Banjal noun class system in creating an irregularity, which is not fully explainable unless the etymology of the item is known. This example illustrates how profoundly language contact can influence the noun class systems of languages in this area and how important it is to take language contact and morphosyntactic properties of the donor languages of loanwords into account.

\subsection{Class ka- as nominaliser of loan verbs}

Gubaher class $k a$ - seems to be in the first place a locative class, since it includes nouns like $k a-l a k$ 'field' ka-muk 'end point, limit' (-muk 'to end') kan-tig 'place' and local reference in connection with the relative marker ka-gini 'the place, where (Rel.)'. In all Baïnounk languages, and at least some Joola languages ( $c f$. Sagna 2008), verb stems can be nominalised by combining them with a noun class marker. In Gubaher the most commonly used noun class markers for this purpose are $b u$ - and $g u$-, though nouns can also take many of the other class prefixes. Surprisingly, $k a$ - is used predominantly for the nominalisation of loan verbs in Baïnounk Gubaher, often in free variation with the most common nominaliser $b u$-. We find ka-pentire and bu-pentire (from French 'peinturer') for 'to paint/painting.' ka-zwe (from French 'jouer') 'play', ka-fay (from Wolof jang 'read') 'read'. Apart from loanwords, $k a$ - is rarely combined with verb stems in Baïnounk Gubaher. It might not be a coincidence that in many Joola languages (Banjal, Kaasa, Fogny) $k a$ - is one of the most frequent noun class prefixes used for nominalisation in general, and also with loan verbs. I strongly suspect that the use of the noun class marker $k a$ - for the purpose of nominalising verb stems in Gubaher is a result of contact influence from surrounding Joola varieties, where this is the most common prefix for verb nominalisation. The fact that $k a$ - in Gubaher is used almost exclusively for loan verbs strengthens this hypothesis. However, the mechanisms of nominalisation are not yet understood and are subjects of ongoing research, so this hypotheses remains to be proven with more conclusive data.

\subsection{Verbal reduplication}

In Baïnounk Gunyaamolo as well as in Joola Fogny verbal duplication is part of the tense/aspect system. Both languages employ reduplicated stems for the expression of perfective aspect: 
(32) a-gir-gir

3SG-run-run

'He ran.'

Gunyaamolo, (Doneux 1990:178)
(33) na-ja-jaw

3SG-go-RED

'She went.'

Joola Fogny, (Gero 2002:10)

Doneux (1990) remarks that verb reduplication is common in many branches of the Atlantic phylum (Bak, Nuun, Seerer, Cangin), but it seems that the use of this mechanism to express verb aspect is typical for the languages spoken in Fogny-influenced surroundings:

\footnotetext{
Quant aux parlers ñuun, on peut noter que seuls les groupes qui sont dans un environnement jamat [Fogny] connaissent la réduplication dans un temps verbal. Ceux qui, comme le jaaxet, sont dans un environnement manjaku l'ignorent. Ceci est une assez bonne indication de calque typologique, et il n'y a guère matière à soupsconner une pratique déjà inscrite en *Atlantique (Doneux 1990:180).
}

In line with Doneux' statement, Baïnounk Gubaher, which is not spoken in a Fogny environment, does not feature aspectual reduplication either. However, we do find reduplicated verb stems (ex. 34), but with an intensifying function: 'to do something intensely or thoroughly'.

\section{(34) i-la:m-i gu-la:m doxs amu \\ 1SG-forget-ASP gu-forget work DEM:AGR \\ 'I totally forgot this work.'}

In elicitation every verb was eligible for this kind of reduplication; the prefix on the reduplicated verb is always $g u$-. Viewed in isolation it is not easy to explain which function the prefix $g u$ - has in these cases: is it a class marker, a specific marker used only in reduplications, an intensifier or something else? If we have a look at an example of reduplication in Manjaku we see that the constructions in Baïnounk Gubaher (34) and in Manjaku (35) are structurally and semantically parallel:

\section{(35) ma fin kë-fin u-lemp wi}

1SG forget CL-forget CL-work DEM:AGR

'I (totally) forgot this work. (Original: J'ai oublié d'oubli ce travail)'

Manjaku, (Doneux 1990: 179)

The function of the Manjaku construction is, as in Baïnounk Gubaher, to intensify the action, apparently without temporal or aspectual properties. Doneux interprets this as a cognate object construction analogous to the French example rire un bel rire 'laugh a nice laugh' with the class marker $k \ddot{e}$ - as nominalising infinitive prefix. Considering the structural and semantic parallels of (34) and (35), it might be worth applying Doneux' cognate object hypothesis proposed for Manjaku to Baïnounk Gubaher. This is supported by the fact that the class marking prefix $g u$ - in Baïnounk Gubaher is one of the most commonly used nominalisers for verb stems.

Although there seem to be areally conditioned patterns in the distribution of verb reduplication with aspectual properties in the Fogny area and with intensificational properties elsewhere, there is not yet enough evidence to propose a conclusive analysis. Detailed data on reduplication will now be needed to see how other languages spoken in the area fit in this pattern. Only then can the following questions be answered: are the two types of reduplication areally distributed? Is one of the types more basic while the other is an innovation? Are there more than two types of verbal reduplication? 


\section{Conclusion and outlook: What kind of data do we need ?}

Before adressing some general notions about the role of language contact in highly multilingual environments, let us quickly resume the core assumptions and hypotheses promoted in this paper. Generally, I have intended to show the pervasiveness of language contact in the Casamance region on the example of Baïnounk by giving an account of the linguistic landscape Baïnounk Gubaher is part of and providing examples for contact phenomena. A second focus of this paper lies on the development of the noun class system of Baïnounk Gubaher, again taking into account the ways contact with other languages has shaped it. The following points have been established:

- Due to historical, distributional and cultural factors the Baïnounk languages have been in intense contact with numerous surrounding languages, with the result that language contact is an essential part in the analysis of the Casamance languages.

- In addition to being heavily influenced through contact with other languages, Baïnounk in turn has very probably been a source/substratum language for other languages of the region too. (see section 0, 0 vocabulary in Kujirerai and section 7.1; $j i$ - in Joola Banjal)

- Litterative alliterative concord (LAC) is not a productive mechanism in Baïnounk ( section 5.1) and the plural suffixes do not seem to be borrowed but are rather the outcome of language internal developments involving animacy (section 5.2).

- The large number of borrowed nouns has an influence on the development of the noun class system by expanding the group of prefixless/suffixing nouns which in turn leads to the spreading of the plural suffix (section 6).

Undoubtedly, much can be gained for the field of areal linguistics but also for the sake of a complete and meaningful basic grammatical analysis of individual languages, if it is possible to compare data on micro-variation within and beyond one language or variety. In order to interpret variation, it would be very beneficial if it was made clear exactly where the data were collected, and if other detailed demographic and sociolinguistic metadata are available. Another important area of information is which languages are used by the community other than the one in the focus of the research, and in which circumstances. We would also want to take into account where and how variation occurs. Variation is, in this case of intense multilingualism and language contact, not simply the result of incomplete or insufficient language skills but an important clue as to where language change is happening and how it is motivated. As a tool, pandialectal dictionaries and in-depth analyses of different varieties and dialects, even if very closely related to each other, can deliver the data needed for working out which major grammatical and lexical features are part of common inheritance, and which ones appear to be contact-induced. We have seen in the example of the noun class systems of Gubaher and Gunyaamolo that it is difficult to understand them in isolation, without looking at closely related varieties and contact languages. Many grammars and descriptions already include information on contact influences. Working on a language like Gubaher I can only stress that this information does not merely provide interesting additional facts or secondary information, but is absolutely central in order to gain a complete picture of core areas of grammar.

Also, highly multilingual field settings like the one introduced here invite us to rethink several basic concepts. As Lüpke (2009) has pointed out, the conditions and criteria for language endangerment in Africa differ enormously from cases usually regarded as "prototypical" in this branch of linguistics, which are based on scenarios encountered in Australia or North America. I would like to add that care has to be taken not to apply other concepts shaped in a Western intellectual environment too prematurely to a situation where they possibly do not apply. In an environment where monolinguals are a small minority and 
the knowledge of five languages is nothing extraordinary, where marriages outside the community are frequent and mobility is high, the concepts of mother-tongue and ethnic identity become hard to grasp at best and absurd at worst. Historical and culturally relevant data can be of great help in identifying the areas where language contact might have had an influence on language change.

\section{Abbrevations}

Abbreviations used in glosses

$\begin{array}{ll}\text { Agr } & \text { Agreement marker } \\ \text { Asp } & \text { aspectual marker } \\ \mathrm{Cl} & \text { noun class marker } \\ \text { Det } & \text { Determiner } \\ \text { Dim } & \text { diminutive } \\ \mathrm{Pl} & \text { Plural } \\ \mathrm{Pr} & \text { Prefix } \\ \text { Red } & \text { Reduplication } \\ \mathrm{Sg} & \text { Singular } \\ & \\ \text { Language names used } & \text { Also used elsewhere } \\ \text { in this text } & \\ & \\ \text { Joola Banjal } & \text { Gusi(i)lay, Gújjolaay Eegimaa, Gubanjalay } \\ \text { Joola Kujirerai } & \text { Hulon, Kuluunaay } \\ \text { Joola of Affiniam } & \text { Gusilay, Joola Buluf } \\ \text { Joola Fogny } & \text { Kujamutay, Kujamat, Jamat } \\ \text { Kriolu } & \text { Portuguese Creole, Guinea Bissau Creole } \\ \text { Baïnounk } & \text { Baïnouk, Bañun, Banhum, Bainunk, Nun, } \\ & \text { Guñun(o) } \\ \text { Kobiana } & \text { (Gu)buy } \\ \text { Kasanga } & \text { (Gu)haaca } \\ \text { Bä̈nounk Gujaxer } & \text { Jaaxet } \\ & \\ \text { Abbreviations used in text } & \\ \text { fr. } & \text { French } \\ \text { LAC } & \text { Litteral Alliterative Agreement } \\ \text { PPFS } & \text { Principle of Phonology-Free Syntax }\end{array}$

\section{References}

Aronoff, Mark. 1997. Gender Agreement as Morphology. In: Geert Booij et al. (eds.). Proceedings of the first Mediterranean conference of morphology. Patras: University of Patras, 7-18.

Avezac, Marie Armand Pascal d' (éd.). 1845. Vocabulaires Guiolof, Mandingue, Foule, Saracolé, Sérère, Bagnon et Floup. Mémoires de la Société Ethnologique (Paris) II, 205-267.

Bassène, Alain-Christian. 2006. Description du Jóola Banjal (Sénégal). Thèse de doctorat. Université Lumière, Lyon 2.

Basso Marques, J. 1947. Familiaridade idiomática entre Cobianas e Cassangas. Boletím Cultural da Guinea Portuguesa 2-8: 875-913. 
Bühnen, Stephan. 1988. Lexique comparatif des dialectes Bañun et de Kasanga et Cobiana, Bremen.

Bühnen, Stephan. 1992. Place names as an historical source: an introduction with examples from southern Senegambia and Germany. History in Africa 19:45-101.

Bühnen, Stephan. 1994. Geschichte der Bainunk und Kasanga. PhD thesis, Fachbereich Geowissenschaften und Geographie, Justus Liebig Universität Giessen.

Childs, George Tucker. 1983. Noun class affix renewal in south West Atlantic. In: Kaye, J. D., H. Koopman, D. Sportiche and A. Dugas. (eds.). Current approaches to African linguistics II. Dordrecht : Mouton de Gruyter - Foris Publications, 17-29.

Diagne, Mbacké. 2009. Le Bayot. Langue Atlantique Nord, groupe bak, sous groupe jóola. Thèse de doctorat. Paris: Institut National des Langues orientales (INALCO).

Dimitriadis, Alexis. 1997. Alliterative Concord in phonology-free syntax. Paper presented at the GLOW Workshop on the Morpho-Syntax and Phonology of African and AfroAsiatic Languages. Rabat, Morocco.

Dobrin, Lise M. 1995. Theoretical consequences of literal alliterative concord. In: Audra Dainora et al. (eds). Papers from the $31^{\text {st }}$ regional meeting of the Chicago Linguist Society, 127-142.

Dobrin, Lise M. 1998. The morphosyntactic reality of phonological form. In: Geert Booij and J. van Marle. (eds). Yearbook of Morphology, 1997. Dordrecht: Kluwer Academic Publisher, 59-81.

Doneux, Jean Léonce 1975. Hypothèse pour la comparative des langues atlantiques. Africana Linguistica 6:41-130.

Doneux, Jean Léonce et Jean Louis Rougé. 1988. En apprenant le Créole à Bissau ou Ziguinchor. Paris : L'Harmattan.

Doneux, Jean Léonce. 1990. Le place de la langue Buy dans le groupe atlantique de la famille Kongo-Kordofan. Thèse de doctorat, Université Libre de Bruxelles.

Dreyfus, Martine et Caroline Juillard. 2004. Le plurilinguisme au Sénégal. Paris : Karthala.

Ferry, Marie-Paule et Konstantin Pozdniakov. 2001. Dialectique du régulier et de l'irrégulier: le système des classes nominales dans le groupe tenda des langues atlantiques. In: Robert Nicolai. (éd.). Leçons d'Afrique. Filiations, ruptures et reconstitution de langues. Un hommage à Gabriel Manessy. Louvain - Paris : Peeters, 153-167.

Gero, Marcia L. 2002. Transitivity in Jola-Fogny. Dakar: Summer Institute of Linguistics (SIL).

Greenberg, Joseph H. 1978. How does a language acquire gender markers? In: Joseph Greenberg et al., Universals of human language 3:47-82. Stanford: Stanford University Press.

Grinevald, Colette. 2000. A morphosyntactic typology of classifiers. In: Gunter Senft. (ed.). Systems of nominal classification. Cambridge: Cambridge University Press, 50-92.

Grinevald, Colette and Frank Seifart. 2004. Noun classes in African and Amazonian languages: Towards a comparison. Linguistic Typology 8-2:243-287.

Heine, Bernd and Derek Nurse. (eds.) 2008. A Linguistic Geography of Africa. Cambridge: Cambridge University Press.

Lespinay, Charles de. 1987. La disparition de la langue Baynunk : fin d'un peuple ou processus réversible?. Contributions à l'histoire du Sénégal. (éd.). Jean Boulègue. Cahiers du C.R.A 5:23-29. (Centre de recherches africaines). 
Lespinay, Charles de. 1996. Autochtonie et droit foncier : l'existence contestée des Baynunk en Afrique de l'Ouest (Sénégal, Gambie, Guinée-Bissau). Droits et Cultures 32:5565 .

Lespinay, Charles de. 1997. Les classes nominales en Baynunk. Cahiers lillois d'économie et de sociologie, numéro spécial : 193-213.

Lespinay, Charles de. 1997a. Un lexique Bagnon-Floupe de la fin du XVII ${ }^{\text {ème }}$ siècle : apport à l'histoire du peuplement de la Casamance. Cahier lillois d'économie et de sociologie, numéro spécial : 193-213.

Linares, Olga. 1992. Power, prayer and production.The Jola of Casamance, Senegal. Cambridge: Cambridge University Press.

Lüpke, Friederike. 2009. At the margin - African endangered languages in the context of global endangerment discourses. African Research and Documentation 109:15-41.

McLaughlin, Fiona. 1997. Noun classification in Wolof: When affixes are not renewed. Studies in African Linguistics 26-1:1-28.

McLaughlin, Fiona. 2009. The ascent of Wolof as an urban vernacular and national lingua franca in Senegal. In: Cécile Vigouroux and Salikoko Mufwene. (eds.). Globalization and language vitality: Perspectives from Africa. London: Continuum Publishers, 203249.

Mark, Peter. 1992. The wild bull and the sacred forest. Cambridge: Cambridge University Press.

Nekitel, Otto. 1986. A sketch of nominal concord in Abuq (An Arapesh language). In: Papers in New Guinea linguistics 24, Pacific Linguistics, Series A, $\mathrm{n}^{\circ}$. 70. Canberra: Australian National University, 177-205.

Nogueira, A. 1947. Monografia sôbre a tribu banhun. Boletim cultural da Guiné Portuguesa 2:973-1008.

Pozdniakov, Konstantin. 1993. Сравнительная грамматика атлантических языков. (Comparative historic grammar of the Atlantic languages). Moscow: Nauka.

Pozdniakov, Konstantin. 2010. La classification nominale : à la croisée des paradigmes. In: Franck Floricic. (éd.). Essais de typologie et de linguistique générale. Paris : ENS Éditions, 87-105. (École Normale Supérieure Lettres et Sciences humaines).

Roche, Christian. 1976. Conquête et résistance des peuples de Casamance (1850-1920). Dakar - Abidjan: Les Nouvelles Éditions Africaines.

Roche, Christian. 2000. Histoire de la Casamance : Conquête et résistance 1850-1920. Paris: Karthala.

Rodney, Walter 1969. Upper Guinea and the Significance of the Origins of Africans Enslaved in the New World. The Journal of Negro History 54-4:327-345.

Rougé, Jean-Louis. 2004. Dictionnaire étymologique des créoles portugais d'Afrique. Paris: Karthala.

Sagna, Serge. 2008. Formal and semantic properties of the Gújjolaay Eegimaa (A.k.a Banjal) nominal classification system. PhD Dissertation, School of Oriental and African Studies (SOAS), London.

Sapir, J. David. 1971. West Atlantic: An inventory. In: Thomas Sebeok. (ed.). Current trends in linguistics 7. Den Haag - Paris: Mouton, 45-112. 
Sauvageot, Serge. 1967. Note sur la classification nominale en Baïnouk. In: La classification nominale dans les langues négro-africaines. Paris: Centre National de la Recherche Scientifique (C.N.R.S), 225-136.

Sauvageot Serge. 1973. Une carte de villages Baïnouk de Casamance (Sénégal). In: Les langues dans le monde ancien et moderne: Afrique subsaharienne. Paris: Centre National de la Recherche Scientifique (CNRS).

Sauvageot, Serge. 1987. La linguistique en tant que témoignage historique: Le cas du Baynunk. Contributions à l'histoire du Sénégal, Jean Boulègue (éd.). Cahier du C.R.A 5:17-22. (Centre de recherches africaines).

Sauvageot, Serge. 2001. De quelques procédés de mise en relief en Baynunk. In: Robert Nicolaï. (éd.). Leçons d'Afrique. Un hommage à Gabriel Manessy. Louvain - Paris: Peeters, 43-55.

Tastevin, Constant F. 1936. Vocabulaires inédits de sept dialectes sénégalais dont six de Casamance. Journal de la Société des Africanistes 6-1:1-33.

Tendeng, Odile. 2007. Le Gusiilay: un essai de systématisation. Une contribution à l'étude du Jóola (Publications Universitaires Européennes, Série XXI, vol. 258). Bern: Peter Lang.

Wilson, Wiliam A. A 2007. Guinea Languages of the Atlantic Group. Description and Internal Classification. (Schriften zur Afrikanistik 12, ed. Anne Storch). Frankfurt am Main: Peter Lang.

Zwicky, Arnold M. and Geoffrey K. Pullum 1986. The Principle of Phonology-Free Syntax: Introductory remarks. Ohio State Working Papers in Linguistics 32:63-91. 
